\title{
Quality of Vermicompost Prepared from Bombax Ceiba Flowers in Presence of Different Quantities of Cow Dung with or without Nutrient Additives
}

\author{
A K Sannigrahi* and Debanjan Sannigrahi \\ Advanced Management Institute for Training \& Achievement, India \\ Submission: July 20, 2018; Published: September 24, 2018 \\ "Corresponding author: Sannigrahi AK, Advanced Management Institute for Training \& Achievement, Persiana, Casa Rio, Palava city, Kalyan - Shil \\ Road, Nilje, Dombivali East, Thane, Maharashtra, India, Tel: 919437436081; Email: sannigrahi_ak@rediffmail.com
}

Abstract

Huge quantity of Bombax ceiba flowers remains unutilized for beneficial purpose and burnt as wastes by villagers. The vermicomposting experiment showed that good quality nutrient rich vermicompost having $1.13 \% \mathrm{~N}, 0.48 \% \mathrm{P}, 2.68 \% \mathrm{~K}, 0.55 \% \mathrm{Ca}, 0.69 \% \mathrm{~S}$ and $2.29 \% \mathrm{Na}$ could be prepared within 57 days from a mixture of equal quantity of flower and cow dung with the help of Eisenia fetida earthworms. Vermicomposting of this flower was also possible with addition of one fourth or even no cow dung. Flower cow dung ratio, however, played a significant role in effective vermicomposting of Bombax ceiba flowers. Application of nutrient additives like $0.5 \%$ urea, $0.5 \%$ rock phosphate and $2.5 \%$ Mahua seed cake during initial preparation of compost beds helped to improve nutrient status of vermicompost. Vermicomposting being easy and low-cost procedure should be followed by villagers for beneficial utilization of these beautiful flowers.

Keywords: Beneficial utilization of waste flowers; Bombax cieba Linn; Eisenia fetida; Quality of vermicompost; Simul flower and Vermicomposting of Flowers

\section{Introduction}

Bombax ceiba Linn, (Family: Bombacaceae), is a straight tall trunk tropical deciduous tree commonly known as red silk cotton tree, Indian red Kapok tree, Shimul (in Bengali), Semal (in Hindi), Sumbal (in Panjabi) and Ximolu (in Assamese). The tree is well known for its beautiful crimson red flowers with 5 petals; usually appear in the spring (March / April) before the new foliage. The flowers are used in some places to make natural colour for Holi the festival of colours in India. Water extract of this flower has also been found to be useful as a natural acid base indicator safer than synthetic indicators [1]. This tree is grown throughout India and other parts of tropical and subtropical Asia (Vietnam, Thailand, Malaysia, Indonesia, southern China, Taiwan and eastern parts of Pakistan, etc.), Australia and Africa. The plant is popular among the tribal communities for the treatment of various diseases. Almost every part of these trees i.e. the seeds, flowers, roots, and barks have a long history of medicinal uses. The paste of flowers and leaves are applied externally to relieve swellings, boils, and various skin conditions. The flowers, which exhibit hepatoprotective effect due to its antioxidant potential, are also used as home remedy for the treatment of jaundice and spleen enlargement [2]. This tree is very useful for soil conservation as well as reclamation of wastelands, mine spoils and barren areas. Though flowers have medicinal value, but huge quantities of flowers are found lying unused under the trees during flowering season. Poor people usually collect these flowers as waste material for burning as cooking fuel. Sannigrahi [3] showed that both flowers and dry leaves of Bombax ceiba were good resource materials for preparing nutrient rich vermicompost with the help of Perionyx excavatus earthworms. Since vermicompost plays an important role in the success of organic farming preferred worldwide, vermicomposting of different organic waste materials is gaining importance. With the modernization of farming technology cattle rearing is also drastically reduced by marginal farmers in India, resulting less availability of cow dung in village level which ultimately hinders the promotion of vermicomposting among villagers [4]. Cow-dung is essential for vermicomposting of any organic wastes since it reduces the carbon nitrogen ratio of the composting materials, helps as starter medium to multiply microorganisms required for decomposition of wastes and acts as food for initial nourishment of epigenic earthworms.

But people sometimes mix cow dung, less or more, with organic wastes depending on its availability during vermicomposting. Sannigrahi and Chakrabortty [5] reported that vermicompost, prepared from leaves of cabbage (Brassica oleracea var. capitata), cauliflower (Brassica oleracea var. botrytis) and knolkhol (Brassica oleracea var. gongylodes) mixed with half quantity of cow dung (weight wise) using Eisenia fetida earthworms, were found to have significantly higher nutrient contents than those 
prepared after mixing with one fourth, equal or double quantity of cow dung. Addition of different nutrient additive such as urea, rock phosphate and muriate of potash with raw materials before vermicomposting also has some impact on vermicomposting and quality of vermicompost [6]. Not much research on these lines has been done on vermicomposting of Bombax ceiba flowers. An attempt was, therefore, made to find out the requirement of optimum quantity of cow dung for vermicomposting of those beautiful but unused flowers and also to evaluate the quality of vermicompost prepared adding some nutrient additives like urea, Purulia rock phosphate and Mahua (Madhuca indica) seed cake during initial bed preparation.

\section{Materials and Methods}

About $140 \mathrm{~kg}$ Bombax ceiba flowers were collected in April 2017. $5 \mathrm{~kg}$ flowers of each was mixed thoroughly with different quantities of cow dung $(1.25 \mathrm{~kg}, 2.5 \mathrm{~kg}, 5 \mathrm{~kg}$ and $10 \mathrm{~kg}$ ) after making slurry with water separately in triplicate and made heap on the cemented floor inside a room. Other 12 beds were prepared simultaneously by mixing $5 \mathrm{~kg}$ flowers with $5 \mathrm{~kg}$ cow dung following similar way. Among these 12 beds, each three beds were mixed with $50 \mathrm{gm}$ urea, 50gm Purulia rock phosphate, $50 \mathrm{gm}$ Mahua seed cake and 250 gm Mahua seed cake separately. Three beds were also made as control treatment by taking only $5 \mathrm{~kg}$ flowers each mixed with sufficient water for making those beds moist like other beds. All beds were arranged in randomized block design inside the room and covered each separately with black polythene sheet for facilitating initial temperature rise in the beds, quick decomposition of flowers and avoiding breeding of fly and other insects. Treatment details are mentioned in Table 1. The powdered Purulia Rock Phosphate (100 mesh) contained $9.87 \%$ total $\mathrm{P}, 0.004 \%$ water soluble $\mathrm{P}, 1.25 \%$ citrate soluble $\mathrm{P}$, $8.62 \%$ citrate insoluble $\mathrm{P}, 7.8 \% \mathrm{Ca}, 5.6 \% \mathrm{Mg}$ and $0.87 \% \mathrm{Fe}$ [7]. Mahua seed cake, on the contrary, contained $2.5 \%$ Nitrogen, $0.8 \%$ Phosphate $\left(\mathrm{P}_{2} \mathrm{O}_{5}\right), 1.2 \%$ Potash $\left(\mathrm{K}_{2} \mathrm{O}\right)$ and $0.3 \%$ Sulfur. Cow dung, however, had $0.5 \%$ Nitrogen, $0.4 \%$ Phosphate and $0.3 \%$ Potash. Beds were thoroughly mixed twice after seven and fifteen days to avoid any dry un-decomposed portion and heaps were made every time. Fifty numbers healthy adult Eisenia fetida earthworms were released on the top of the mixture after second mixing and beds were covered with moist gunny bags replacing polythene sheet for facilitating proper moisture and aeration. Regular monitoring was done to maintain about 80 percent moisture in the beds by spraying water from hand sprayer and to protect earthworms from predators like frogs and red ants. After completion of vermicomposting as observed by physical verification, the black coloured loosely granular vermicompost from each bed was spread in the shade for partial air drying after separating earthworms by hand picking. Weight of vermicompost from each bed was recorded after sieving through $2 \mathrm{~mm}$ sieve and samples were kept in plastic bottles separately for chemical analysis.

Table 1: Treatment details with quantity of vermicompost harvested.

\begin{tabular}{|c|c|c|c|c|c|c|}
\hline \multirow{2}{*}{ Treatment Nos. } & \multicolumn{2}{|c|}{$\begin{array}{c}\text { Materials mixed with } 5 \mathrm{~kg} \text { Bombax } \\
\text { ceiba flowers }\end{array}$} & \multirow{2}{*}{$\begin{array}{l}\text { Flower cow } \\
\text { dung ratio }\end{array}$} & \multirow{2}{*}{$\begin{array}{l}\text { Days of harvesting } \\
\text { of vermi-compost }\end{array}$} & \multirow{2}{*}{$\begin{array}{l}\text { Vermi-compost } \\
\text { harvested (kg) }\end{array}$} & \multirow{2}{*}{$\begin{array}{l}\text { Moisture }(\%) \text { in pro- } \\
\text { cessed vermi-compost }\end{array}$} \\
\hline & Cow dung (kg) & Nutrient additives (g) & & & & \\
\hline 1 & 0 & 0 & Control & 71 & $1.2(24)^{*}$ & 250.4 \\
\hline 2 & 1.25 & 0 & 01:00.3 & 64 & $2.0(32)$ & 216.3 \\
\hline 3 & 2.5 & 0 & 01:00.5 & 64 & $3.0(40)$ & 133.7 \\
\hline 4 & 5 & 0 & 1:01 & 57 & $5.4(54)$ & 102.6 \\
\hline 5 & 10 & 0 & 1:02 & 68 & $8.2(55)$ & 66.8 \\
\hline 6 & 5 & Urea - 50g & 1:01 & 57 & $6.5(65)$ & 111.5 \\
\hline 7 & 5 & R P - 50g & 1:01 & 57 & $5.0(50)$ & 84.1 \\
\hline 8 & 5 & M cake - 50g & 1:01 & 57 & $5.2(52)$ & 76.7 \\
\hline 9 & 5 & M cake $-250 \mathrm{~g}$ & 1:01 & 57 & $5.5(55)$ & 82.5 \\
\hline
\end{tabular}

*Percentage of bed materials harvested as vermicompost

The $\mathrm{pH}$ of vermicompost samples was determined from 1:2 compost: water mixtures using Systronics digital $\mathrm{pH}$ meter. Total nitrogen was estimated following Kjeldahl digestion and distillation method. Total Potassium, Sodium and calcium were determined using flame photometer while Phosphorus and Sulfur using spectrophotometer from the extract of Diacid (Conc. HNO3 and $\mathrm{HClO4}$ ) digestion of samples [8]. Results were calculated on oven dry basis and analyzed statistically.

\section{Results and Discussion}

Since flowers were soft in nature, vermicomposting was quicker and took only 57 to 64 days for converting Bombax ceiba flowers to vermicompost by Eisenia fetida earthworms in presence of cow dung Table 1. Even in control treatment i.e. without cow dung, vermicomposting was completed in 71 days which was obvious as earthworms took some time to adopt initially in the environment of partially decomposed flowers without cow-dung. 
Addition of cow dung with flowers in 1:1 ratio became more favourable to earthworm for vermicomposting with lesser time. Addition of nutrient additives did not show any effect in case of completion of vermicomposting. However, more cow dung application with flowers (2:1 ratio) delayed vermicomposting.

The harvesting data showed that about 50 percent bed materials could be harvested as vermicompost when equal quantity of flowers and cow dung were mixed and fed to earthworms. Mixing with less quantity of cow dung resulted less percentage of vermicompost production indicating noncompletion of vermicomposting of flowers with less or no addition of cow dung. Among nutrient additives, 0.5 percent urea addition recorded higher harvesting of vermicompost (65\%), might be due to favourable change in carbon nitrogen ratio, while other remained ineffective in relation to vermicompost production. It is also interesting to note that vermicompost produced from Bombax ceiba flowers with less quantity of cow dung hold more moisture in comparison to other treatments after harvesting, partial air drying and sieving. Comparatively less moisture content in vermicompost was recorded in treatment 5 where maximum quantity of cow dung was mixed with flower. The result,

Table 2: Total macro-nutrient status of vermicompost. therefore, showed that flower-cow dung ratio played a significant role in vermicomposting. The $\mathrm{pH}$ of vermicompost as presented in Table 2 was neutral in nature which decreased slightly with more addition of cow dung. Lowest pH (5.2) was, however, recorded in Treatment 9 where extra 250g Mahua cake was added with $10 \mathrm{~kg}$ flower-cow dung (1:1) mixture. Total nitrogen content of vermicompost prepared from only Bombax ceiba flowers was found maximum $(2.29 \%)$ which gradually decreased to $0.71 \%$ with addition of more and more cow dung. This might be due to dilution effect as cow-dung contained less quantity of nitrogen than flowers. Similar dilution effect due to addition of cow dung during vermicomposting of leaves of cole crops was also reported earlier [5]. Addition of urea and mahua cake increased the nitrogen status in vermicompost due to availability of more nitrogen in them as compared to cow dung. Conservation of nitrogen might have taken place due to increase in cellulolytic microorganisms in compost beds by decreasing denitrifying bacteria with addition of nutrient additives [9]. Equal quantities of Flower - cow dung mixture (Treatment 4) recorded comparatively better nitrogen status probably due to better microbial and earthworm activities.

\begin{tabular}{|c|c|c|c|c|}
\hline \multirow{2}{*}{ Treatment Numbers } & \multirow{2}{*}{ pH (1:2) } & \multicolumn{3}{|c|}{ Total nutrients (\%) } \\
\cline { 2 - 5 } & 6.8 & Nitrogen & Phosphorus & $5.68 \pm 0.07$ \\
\hline 1 & 6.8 & $2.29 \pm 0.04$ & $0.68 \pm 0.03$ & $3.36 \pm 0.06$ \\
\hline 2 & 6.8 & $1.64 \pm 0.04$ & $0.61 \pm 0.03$ & $1.85 \pm 0.05$ \\
\hline 3 & 6.2 & $0.87 \pm 0.02$ & $0.54 \pm 0.03$ & $2.68 \pm 0.08$ \\
\hline 4 & 6 & $1.13 \pm 0.03$ & $0.48 \pm 0.02$ & $1.48 \pm 0.03$ \\
\hline 5 & 6.5 & $0.71 \pm 0.04$ & $0.46 \pm 0.02$ & $1.61 \pm 0.04$ \\
\hline 6 & 6.3 & $1.17 \pm 0.03$ & $0.47 \pm 0.04$ & $1.36 \pm 0.05$ \\
\hline 8 & 6.2 & $0.98 \pm 0.03$ & $0.71 \pm 0.02$ & $1.43 \pm 0.04$ \\
\hline 9 & 5.2 & $1.06 \pm 0.02$ & $0.48 \pm 0.06$ & $1.52 \pm 0.04$ \\
\hline
\end{tabular}

Table 3: Total calcium, sulfur and sodium contents in flower vermicompost.

\begin{tabular}{|c|c|c|c|}
\hline \multirow{2}{*}{ Treatment Numbers } & \multicolumn{3}{|c|}{ Total contents (\%) } \\
\cline { 2 - 4 } & Calcium & Sulfur & $4.04 \pm 0.04$ \\
\hline 1 & $1.49 \pm 0.07$ & $1.01 \pm 0.11$ & $2.71 \pm 0.06$ \\
\hline 2 & $0.92 \pm 0.04$ & $0.59 \pm 0.08$ & $1.75 \pm 0.04$ \\
\hline 3 & $0.56 \pm 0.04$ & $0.71 \pm 0.07$ & $2.29 \pm 0.05$ \\
\hline 4 & $0.55 \pm 0.05$ & $0.69 \pm 0.07$ & $1.32 \pm 0.03$ \\
\hline 5 & $0.48 \pm 0.03$ & $0.56 \pm 0.09$ & $1.58 \pm 0.03$ \\
\hline 6 & $0.54 \pm 0.04$ & $0.44 \pm 0.02$ & $1.40 \pm 0.03$ \\
\hline 8 & $0.59 \pm 0.03$ & $0.49 \pm 0.03$ & $1.42 \pm 0.03$ \\
\hline 9 & $0.49 \pm 0.03$ & $0.51 \pm 0.04$ & $1.45 \pm 0.02$ \\
\hline
\end{tabular}

Similar to nitrogen, total phosphorus content ( 0.46 to $0.68 \%$ ) was also found higher in vermicompost prepared from flowers only and reduced gradually with addition of more quantity of cow dung. Addition of rock phosphate and Mahua cake during vermicomposting recorded better phosphorus content due to better phosphatase activity of earthworms. Beneficial 
impact of application of small quantity rock phosphate during vermicomposting of paddy straw was also reported earlier by Sannigrahi et al [6]. Total potassium content was also very high (5.68\%) in vermicompost prepared from flowers alone (Control treatment) and its significant reduction due to dilution effect with addition of more cow dung (containing less potash) was clearly noticed since the added cow dung was having very less quantity of potassium than flowers. Comparatively better major nutrient status in treatments 4, 6 and 9 suggested better earthworm activity under favorable environment. Table 3 depicted analytical data in relation to total calcium, sulfur and sodium content in vermicompost. Calcium, sulfur and sodium contents varied from 0.49 to $1.49 \%, 0.44$ to $1.01 \%$ and 1.32 to $4.04 \%$ respectively and showed similar trend like major nutrients discussed earlier, confirming clear dilution effect with addition of more cow dung with Bombax ceiba flowers. Application of Mahua cake and Rock phosphate during vermicomposting showed some positive impact on availability of these nutrients.

\section{Conclusion}

Vermicomposting experiment and chemical analysis of processed vermicompost, therefore, proved that Bombax flowers was a good resource material for producing nutrient rich good quality vermicompost and should not be wasted by burning. Flowers mixing with equal quantity (weight wise) of cow dung were recorded as the best mixture for efficient vermicomposting and that was even possible with less or no cow dung. Addition of $0.5 \%$ urea, $0.5 \%$ rock phosphate and $2.5 \%$ Mahua seed cake recorded improvement in quality of vermicompost by increasing nutrient status and earthworm activity. Flower-cow dung ratio played a significant role on vermicomposting of Bombax ceiba flowers.

\section{References}

1. Jain V, Verma SK (2012) Pharmacology of Bombax ceiba Linn. Springer Briefs in Pharmacology and Toxicology.

2. Wanjari MM, Gangoria R, Dey YN, Gaidhani SN, Pandey NK, et al. (2016) Hepatoprotective and antioxidant activity of Bombax ceiba flowers against carbon tetrachloride- induced hepatotoxicity in rats. Hepatoma Research 2: 144-150.

3. Sannigrahi AK (2009) Biodegradation of leaf litter of tree species in presence of cow-dung and earthworms. Indian Journal of Biotechnology 8(3): 335-338.

4. Sannigrahi AK (2016) Major constraints in popularizing vermicompost technology in eastern India. Modern Environmental Science and Engineering 2(2):123-133.

5. Sannigrahi AK, Chakrabortty S (2008) Influence of waste cow dung ratio on chemical quality of vermicompost of Cole crop leaves. Environment \& Ecology 10(4): 863-865.

6. Sannigrahi AK, Chakrabortty S, Borah M (2003) Vermicomposting of Paddy Straw pretreated with chemical fertilizers. Indian Journal of Environmental Protection 23(7): 737-740.

7. Roy T, Biswas DR, Datta SC, Dwivedi BS, Lata, et al. (2015) Solubilization of Purulia Rock Phosphate Through Organic Acid Loaded Nanoclay Polymer Composite and Phosphate Solubilizing Bacteria and its Effectiveness as P-fertilizer to Wheat. Journal of the Indian Society of Soil Science 63(3): 327-338.

8. Bhargava BS, Raghupathi HB (1993) Analysis of plant materials for macro and micronutrients. In: Tandon HLS (Ed), Methods of Analysis of Soils, Plants, Waters and Fertilizers, Fertilizer Development and Consultation Organization, New Delhi, pp. 49-82.

9. Karokin MA (1952) The utilization of rock phosphate flour for organomineral composts. Soviet Agronomy 10: 57.

\section{Your next submission with Juniper Publishers will reach you the below assets}

- Quality Editorial service

- Swift Peer Review

- Reprints availability

- E-prints Service

- Manuscript Podcast for convenient understanding

- Global attainment for your research

- Manuscript accessibility in different formats

( Pdf, E-pub, Full Text, Audio)

- Unceasing customer service

Track the below URL for one-step submission https://juniperpublishers.com/online-submission.php 